\title{
Hvilke prosjekter skal legges frem for regional etisk komité?
}

\author{
Det har lenge rådet usikkerhet omkring hvorvidt såkalte kvalitetssikringsprosjekter krever godkjenning fra \\ regional etisk komité. Helseforskningsloven fra 2009 klargjorde at dette ikke er tilfellet, like fullt er det tvils- \\ tilfeller og gråsoner. For å oppnå en mest mulig enhetlig praksis har de sju komiteene publisert et «knagge- \\ dokument» med konkretisering av hva de mener skiller kvalitetssikring fra fremleggelsespliktige prosjekter.
}

De regionale komiteer for medisinsk og helsefaglig forskningsetikk (REK) skal forhåndsgodkjenne forskningsprosjekter «som utføres med vitenskapelig metodikk for å skaffe til veie ny kunnskap om helse og sykdom» (1). Det er altså formålet med prosjektene som er utslagsgivende for fremleggingsplikten. I Helse- og omsorgsdepartementets veileder til loven heter det at «kvalitetssikring kan defineres som prosjekter, undersøkelser, evalueringer o.1. som har til formål å kontrollere at diagnostikk og behandling faktisk gir de intenderte resultater» (2). Prosjekter som har et slikt formål, faller i utgangspunktet utenfor helseforskningslovens virkeområde, dvs. at godkjenning fra regional etisk komité ikke kreves. Kvalitetssikring anses nemlig som en integrert del av helsetjenesten og reguleres av de ordinære lover og regler for denne. Dette innebærer bl.a. at kvalitetssikringsprosjekter bør forelegges Personvernombudet med henblikk på korrekt behandling av helse- og personopplysninger og samtykkespørsmål. Videre skal et kvalitetssikringsprosjekt bare gjennomføres når ansvarlig ledelse, til vanlig avdelingsleder, har godkjent det og stiller de nødvendige ressurser til rådighet.

Til tross for denne avklaringen er det fortsatt slik at det kan oppstå tvil om fremleggingsplikten for regional etisk komité. Landets sju komiteer har utarbeidet en nærmere beskrivelse av hva de mener kjennetegner hhv. fremleggingspliktige og ikke-fremleggingspliktige prosjekter (3). Vi vil her gjøre rede for noen hovedlinjer, men viser til «knaggedokumentet» for detaljer (3).

\section{Fremleggingsplikten}

Det er ikke uvanlig at man i diskusjonen om fremleggingsplikten prøver å skille mellom «forskning» og «kvalitetssikring» $i$ den forstand at det ene utelukker det andre. Denne dikotomien er uholdbar. Det er bare en fordel, slik vi ser det, at man ved kvalitetssikring anvender vitenskapelig tilnærming og analyse. Det utslagsgivende for fremleggingsplikten er og blir formålet med prosjektet.

Når prosjektets formål er «å skaffe til veie ny kunnskap om helse og sykdom», er det fremleggingspliktig. Hva som skal anses som «ny kunnskap» kan naturligvis diskute- res, men hvis man tar sikte på å fremskaffe generaliserbar kunnskap, taler dette for fremleggingsplikt. På den annen side kan det godt tenkes at kvalitetssikringsprosjekter kan frembringe bekreftende kunnskap som er «ny» $\mathrm{i}$ intern sammenheng, men som likevel ikke er generaliserbar og derfor ikke utløser fremleggingsplikt (3).

Dersom prosjektet innebærer utprøvning av noe nytt, må det foretas en risikovurde-

\section{«Det utslagsgivende forfremleggingsplikten er og blir formålet med prosjektet»}

ring som blir sentral for regional etisk komité å vurdere. Dersom prosjektet innebærer noe kvalitativt nytt, taler dette sterkt for at komitégodkjenning er nødvendig. Det samme gjelder randomisering av pasienter og bruk av kontrollgrupper, særlig når det er snakk om friske kontrollpersoner. Utprøvende behandling skal forhåndsgodkjennes av regional etisk komité.

\section{Kvalitetssikring}

Tradisjonen med «å gjøre opp et materiale» på kliniske avdelinger er å regne som klassisk kvalitetssikring for å følge en praksis som har vart noen tid. De fleste slike prosjekter er retrospektive, men kan også kombineres med et prospektivt element ved at pasienter inngår $i$ et såkalt kvalitetsregister som monitorerer virksomheten uten spesifikke forskningsspørsmål. Sammenlikning mellom veletablerte behandlingsalternativer kan også være å anse som kvalitetssikring. Det samme gjelder det å innhente pasientenes erfaring $i$ forbindelse med diagnostikk og behandling, f.eks. ved bruk av spørreskjema. Formålet må altså være å sikre eller evaluere den behandlingen som drives.

\section{Momenter som ikke er relevante} I diskusjonene om fremleggingsplikten etter den nye helseforskningsloven fra 2009 har det vært anført flere momenter som ikke er relevante. Noen søker godkjenning fra regional etisk komité som et vitenskapelig kvalitetsstempel. De regionale komiteer for medisinsk og helsefaglig forskningsetikk er ikke genuine vitenskapskomiteer som karaktersetter prosjektene, men de krever og skal påse at prosjektene har en akseptabel vitenskapelig gehalt og at forskningsspørsmålene med rimelighet kan besvares. Hvis ikke, er det uetisk å plage folk med deltakelse. Mange av avslagene har en slik begrunnelse.

Noen søker regional etisk komité for å oppnå forskningsmidler, andre fordi deres prosjekt skal publiseres og/eller inngå $i$ avhandlinger. Komiteene legger imidlertid til grunn at dette er uavhengige spørsmål som andre instanser skal avgjøre - hhv. finansieringskildene, redaktørene og akademia.

\section{I tvil?}

De regionale komiteer for medisinsk og helsefaglig forskningsetikk er et forvaltningsorgan og bestemmer selv hva som er fremleggingspliktig i enkeltsaker. Avvisningsvedtak skal begrunnes, og da blir prosjektets karakter som kvalitetssikring anført. Vedtak kan påklages til Den nasjonale forskningsetiske komité for medisin og helsefag (NEM). Grenseoppgangen mellom hva som er fremleggingspliktig og hva som ikke er fremleggingspliktig kan være vanskelig. De regionale komiteer for medisinsk og helsefaglig forskningsetikk har derfor laget et forenklet skjema der forskeren i korthet kan skissere sitt prosjekt slik at komiteen kan vurdere fremleggingsplikten uten å gå veien om en fullt utarbeidet søknad (4). Vi anbefaler bruk av dette skjemaet. Forespørslene besvares fortløpende, uavhengig av søknadsfrister. En annen fordel er at både søker og regional etisk komité i ettertid kan dokumentere at spørsmålet har vært vurdert. Komiteen kan også utstede «Letter of exemption» til tidsskriftredaksjoner i forbindelse med publisering av kvalitetssikringsprosjekter.

\section{Jon Lekven}

jon.lekven@kir.uib.no

Sven Erik Gisvold

Jørgen Hardang 
Jon Lekven (f. 1941) er leder av REK Vest. Forfatter har fylt ut ICMJE-skjemaet og oppgir ingen interessekonflikter.

Sven Erik Gisvold (f. 1944) er leder av REK MidtNorge.

Forfatter har fylt ut ICMJE-skjemaet og oppgir ingen interessekonflikter.

Jørgen Hardang (f. 1945) er komitésekretær i REK Sørøst A.

Forfatter har fylt ut ICMJE-skjemaet og oppgir ingen interessekonflikter.
Litteratur

1. Lov om medisinsk og helsefaglig forskning. www.lovdata.no/all/hl-20080620-044.html (2.10.2012).

2. Veileder til lov 20. juni 2008 nr. 44 om medisinsk og helsefaglig forskning. www.regjeringen.no/ upload/HOD/HRA/Veileder $\% 20$ til\%20 helseforskningsloven.pdf (2.10.2012).

3. Kjennetegn som REK bør observere i spørsmål om kvalitetssikring vs. fremleggingspliktige prosjekter. FREK 2.12.2011. http://helseforskning. etikkom.no/ikbViewer/Content/275633/ Kvalitetssikring\%20vs\%20framleggingspliktig\% 20prosjekt\%20FREK\%20des\%202011.pdf (26.9.2012).
4. Framleggingsvurdering. http://helseforskning. etikkom.no/ikbViewer/page/frister/ forskningsprosjekt?p_dim=34769 (2.10.2012).

Mottatt 20.9. 2012, første revisjon innsendt 17.10. 2012, godkjent 18.10. 2012. Medisinsk redaktør Siri Lunde.

Publisert først på nett 2.11. 2012

\title{
Forskes det for mye her i landet?
}

\author{
Vi mener den store oppmerksomheten omkring doktorgraden som det viktigste målet for vitenskapelig \\ virksomhet i Norge er en blindvei. Denne strategien vektlegger kvantitet fremfor kvalitet og reduserer \\ muligheten for å kombinere klinisk arbeid med forskning, noe som er vanlig i mange andre land.
}

Mange vil vel mene at professorer som stiller et slikt spørsmål burde finne seg noe annet å gjøre. På redaksjonelt hold i Tidsskriftet har det imidlertid vært pekt på at det nå publiseres altfor mange artikler som ikke holder tilstrekkelig vitenskapelig kvalitet (1). Representanter for andre fagområder har også gitt uttrykk for liknende synspunkter (2). Etter vårt syn må slike betraktninger ses på bakgrunn av store svakheter og mangler ved organiseringen av norsk forskning. Dette gjelder både omfang, fordeling av midlene - for mye til lønn og for lite til driftsmidler og utstyr - samt organisering, med altfor stor vekt på doktorgradssporet, i hvert fall innen fagområdet medisin, som er det området vi kjenner best til. Den evalueringen av medisinsk forskning som Norges forskningsråd nylig gjennomførte har også pekt på disse problemstillingene (3).

Universitetssykehusene og de medisinske fakulteter konkurrerer hvert år om å frembringe flest publikasjoner og doktorgrader. En doktorgrad (ph.d.-grad) gir status for kandidaten og veilederne, og antallet doktorgrader gir status til institutt, fakultet og universitet. Ved ansettelse i professorater vektes tilsynelatende veiledning av doktorander høyere enn annen akademisk, undervisningsmessig og forskningsmessig meritt.

Det argumenteres ofte med at målet for doktorgradsutdanningen er å gi kandidaten innføring i forskningsteori og dermed økt kompetanse til å vurdere andres forskningsresultater samt til selv å initiere videre forskning. Men gitt volumet av ressursene som investeres, både fra samfunnets og kandidatens side, synes det rimelig å spørre om doktorandene faktisk initierer egen forskning og om forskningsteori og kritisk leseevne kanskje kunne læres like godt på andre måter og med bedre ressursbruk.

\section{Trengs det $\mathbf{4 0 0}$ eller $\mathbf{4 0}$ bakere?}

I 2011 ble det avlagt 1327 doktorgrader i Norge, herav 396 ved de medisinske fakultetene, dvs. en økning på $70 \%$ fra 2007 (4). Ifølge rektor Ole Petter Ottersen ble det avlagt 160 doktorgrader ved Det medisinske fakultet i Oslo i første halvår i 2012, noe som er ny rekord (5). Dette blir mer enn én disputas per dag. Samtidig har

\section{«Svært få leger som tar doktorgraden fortsetter en viten- skapelig karriere»}

undersøkelser de siste årene vist at svært få leger som tar doktorgraden fortsetter en vitenskapelig karriere. Dette kan skyldes flere forhold, bl.a. manglende stillinger på neste karrierenivå, ved at forholdet mellom doktorgradsstipendiater og stillinger som postdoktor eller førsteamanuensis er omtrent 10:1 her i landet. Dette tilsier at de fleste stipendiater ikke har noen mulighet til å komme videre i en forskerkarriere. Denne situasjonen har bl.a. vært drøftet på årskonferansen for Leger i vitenskapelige stillinger (LVS) både i Oslo i 2011 og sist i Tromsø i 2012, der temaet for konferansen var Hvor ble det av legeforskeren etter avsluttet ph.d.-grad? (Dag Bratlid, personlig meddelelse). De som har forsket innen laboratoriefag og eksperimentell medisin har dessuten få muligheter til å videreføre sin forskning hvis de går tilbake til en klinisk stilling.

Man kan derfor spørre seg - med referanse til et fagområde en av oss kjenner godt - hvor fornuftig det er å utdanne 400 bakere dersom det bare er 40 som kan få jobb som baker? Det kan kanskje være nyttig å være utdannet baker for å selge brød i butikken eller kjøre brødbil, men er et svennebrev en effektiv investering av tid og ressurser for å utføre slike jobber? Er den betydningen som tillegges doktorgraden den beste strategien for å gi leger akademisk kompetanse og stimulere til forskning? Lønn til de mange doktorgradskandidatene beslaglegger nå så store deler av instituttenes budsjetter at det kan gå utover andre områder. Norske universiteter synes å bruke en større del av sine budsjetter på lønnsmidler enn universiteter i mange andre land (6).

\section{Vanskelig å kombinere klinisk stilling og forskning}

Forskning er en av hovedoppgavene i sykehus, på linje med diagnostikk og pasientbehandling. Legenes tjenesteplaner inneholder fordypningstid til forskning og fagutvikling som imidlertid er dårlig organisert og ofte blir inndratt ved sykdom og 